relation to the possibility of captures being made (number of trap-settings) rules out reduction of trappability of trap-shy individuals due to blockage of traps by trap-prone individuals caught in them.

The results given therefore show that: 1 ) trap-prone individuals intensively penetrate the whole area of their home range, 2) if the trap-shy characteristic is formed under the influence of the domination of trap-prone individuals, then the effect exerted by the latter applies to the whole of their home range, 3) captures on sites with bait laid out on them increases the percentage of trap-shy individuals in the results in relation to results which would be obtained by trappings on places chosen at random.

\title{
REFERENCES
}

Andrzejewski R., Petrusewicz K. \& Walkowa W., 1959: Preliminary report on results obtained with a living trap in a confined population of mice. Bull. Acad. pol. Sci. Cl. II, 7: 367-370. Andrzejewski R., Petrusewicz K. \& Waszkiewicz-Gliwicz J., 1967: The trappability of Clethrionomys glareolus ( $\mathrm{S}$ chreber, 1780) and other ecological parameters obtained by the CMR capture method. Ekol. pol. A, 15, 35: 709-725. C al h o u n J. B., 1959: Revised sampling procedure for the North American census of small mammals (NACSM). U.S. Dept. Health Educat. Welf. Bethesda, 10: 1-12. Crow croft P. \& Jeffers J. N. R., 1961: Variability in behaviour of wild house mice ( $M$. musculus L.) towards live traps. Proc. zool. Soc. Lond., 137: 573-582. G li w i c z J., 1970: Relation between trappability and age of individuals in a population of the bank vole. Acta theriol., 15, 2: $15-23$. K i k k a w K., 1964: Mobility, activity and distribution of small rodents (Clethrionomys glareolus and Apodemus sylvaticus) in woodland. J. Anim. Ecol., 33: 259-299. Tra c z y k H., 1965: Roślinność »Wyspy Dzikiej Jabłoni « na Jeziorze Bełdańskim (The vegetation of "The Wild Apple-Tree Island " on the Lake Bełdańskie). Fragm. flor. geobot., 11: 541-545.

Institute of Ecology, Polish Academy of Sciences, Dziekanów n. Warsaw. Accepted, May 15, 1971.

Wirgiliusz ŻUROWSKI, Jan KISZA \& Antoni KRUK

\section{COMPOSITION OF MILK}

OF EUROPEAN BEAVERS, CASTOR FIBER L I N N A E US, 1758

SKŁAD MLEKA BOBROW EUROPEJSKICH, CASTOR FIBER L I N N A E U S, 1753

Seven samples of milk were collected from 4 beaver females during various stages of lactation. The application of tranquiline and oxytocin significantly facilitated milk sampling. The beaver milk is characterized by a high dry matter $(24.1 \%)$ fat $(11.7 \%)$ and total protein $(8.9)$ contents, and hence shows a high nutritive value. Marked differences in the milk composition were observed depending on the period of lactation.

The necessity of artificial nursing or additional feeding of beaver kits repeatedly occurs during farm breeding of beavers. The kits are born in well advanced stages of development, covered with fur, and a few 
hours later they open eyes. According to the data from the Popielno farm the beaver weight at birth ranges between 320 and $770 \mathrm{~g}$. In the age of 15 days this weight is already doubled. During lactation stretching for approximately 60 days the beavers reach the mean weight of $3.1(2.0-4.8) \mathrm{kg}$.

The obtaining of similar effects with artificial nursing requires a carefully elaborated method of feeding of beaver kits or supplementing their food. The establishment of proper diet is possible only after the beaver milk composition is known. The only analysis of beaver milk was carried out in Voronezh ( $\mathrm{L}$ a v rov, 1938, 1954). In that case approximately $10 \mathrm{ml}$ of milk was obtained from one female in the middle of the lactation period. The described analysis, however, do not satisfy cognitive and practical requirements. The milk content certainly changes during lactation, and individual differences also cannot be neglected.

The present study was aimed at elaboration of the method of collecting milk from lactating beaver females, and at obtaining preliminary information on the milk composition in various periods of lactation. The experiment was carried out on 4 adult females, weighing $20-26 \mathrm{~kg}$, in

Table 1

Conditions of milk sampling from beaver females.

\begin{tabular}{|c|c|c|c|c|c|c|c|}
\hline No. of animal & 86 & 34 & 34 & 38 & 41 & 38 & 38 \\
\hline & \multicolumn{2}{|c|}{ May } & \multicolumn{3}{|c|}{ June } & & \\
\hline Date of sampling & 9 & 11 & 18 & 6 & 18 & 11 & 18 \\
\hline Age, years & 2 & 8 & 8 & 6 & 6 & 6 & 6 \\
\hline Consecutive lactation & 1 & 7 & 7 & 4 & 3 & 4 & 4 \\
\hline Day of lactation & 2 & 10 & 17 & 38 & 41 & 43 & 50 \\
\hline Tranquiline (mg) & 50 & - & - & - & 50 & - & - \\
\hline Oxytocin (I. U.) & 5 & 7 & 7 & 7 & 7 & 11 & 7 \\
\hline Milk sample volum (ml) & 11 & 12 & 10 & 12 & 20 & 25 & 10 \\
\hline Time required for sampling (min) & 40 & 15 & 15 & 14 & 5 & 20 & 15 \\
\hline
\end{tabular}

the Experimental Farm at Popielno, in the breeding season 1970. Altogether 7 samples of milk were collected from females in various periods of lactation (Table 1). The analyses were carried out in the Institute of Food Engineering and Biotechnology, High School of Agriculture in Olsztyn.

To avoid difficulties encountered by $\mathrm{Lavrov}(1938)$ and $\mathrm{S}$ ław i nski (1966) with collecting milk from beaver and nutria, the experimental animals were pretreated with some drugs. Wild beaver females were treated with tranquiline ( $\mathrm{Z}$ u row ski, 1970) and then with oxytocin in the dose of 5 to $11 \mathrm{I}$. U. Quiet animals obtained only oxytocin. In 3 to $5 \mathrm{~min}$. after intramuscular injection of oxytocin the milk was sampled directly to a test-tube by massaging the gland and pressing nipples with two fingers using pulling movements. The females yielded milk very well. During 5 to $20 \mathrm{~min} 10-25 \mathrm{ml}$ of milk were collected without difficulties. Only during the first sampling the time required for collecting $11 \mathrm{ml}$ of milk amounted to $40 \mathrm{~min}$ (Table 1). The good secretion of milk was related probably to the action of oxytocin. 
The kits were not separated from mothers before milk sampling. It was assumed that the degree of emptying the gland by sucking should not affect significantly the milk composition. L a v r o v (1954) concluded that beaver females secrete milk permanently in small amounts and hence the nipples of a female just taken out of the nest are moist, with signs of recent sucking. On the other hand, separation of kits from the mother for a few hours might later create difficulties with accepting them by the mother, and it is known that disturbing females - often leads to the loss of the litter. The collected samples of milk were cooled and preserved (for $12-24$ hours) in a thermos flask with ice up to the moment of analysis. The first 3 samples were divided in two parts, one heing conserved with potassium dichromate, the other with formalin. Later the conservation of milk with chemical agents was abandoned. The content of particular milk constituents was estimated according to the method described by Budsławski (1963) for the cow milk. The obtained results (Table 2) confirm a high nutritive value of the beaver milk, since the dry matter varies in the range of 21 to $30 \%$. Another

Table 2

Composition of beavers milk.

\begin{tabular}{|l|rrrrrrr|r|r|r|}
\hline \multicolumn{1}{|c|}{ No of animal } & 86 & 34 & 34 & 38 & 41 & 38 & 38 & $\begin{array}{c}\text { After } \\
\text { Avg. } \\
\text { Lavrov } \\
(1954)\end{array}$ \\
\hline Dry matter, \% & 16.3 & 21.6 & 24.2 & 21.9 & 30.0 & 25.7 & 29.1 & 24.1 & - \\
Fat, \% & 5.8 & 8.2 & 10.6 & 11.0 & 17.6 & 12.1 & 16.5 & 11.7 & 16.1 \\
Lactose, \% & 3.5 & 3.8 & 4.3 & 2.5 & 1.3 & 1.6 & 1.5 & 2.6 & 1.7 \\
Total protein, \% & 6.8 & 8.4 & 8.0 & 9.5 & 10.0 & 10.0 & 9.7 & 8.9 & 8.2 \\
Casein, \% & 4.2 & 4.6 & 6.2 & 6.8 & 7.6 & 6.9 & 7.1 & 6.2 & 7.5 \\
Whey proteins, \% & 1.9 & 2.9 & 1.1 & 1.6 & 2.0 & 2.0 & 1.9 & 1.9 & -1.4 \\
Ash, \% & 0.9 & 1.0 & 0.7 & 1.1 & 1.6 & 1.2 & 1.5 & 1.1 & 1.4 \\
Ca, mg \% & 108 & 126 & 97 & 105 & 195 & 83 & 99 & 116 & - \\
P, mg \% & 91 & 107 & 96 & 175 & 174 & 126 & 121 & 121 & - \\
\hline
\end{tabular}

striking feature depends on a high content of fat and total protein, mainly casein. The milk composition changes with lactation. The lowest dry mater values were recorded in the colostrum obtained on the second day of lactation $(16.3 \%$ ). Similarly S ław iński (1966) observed that in nutria the lowest dry matter content was in the colostrum. At later periods of lactation the content of particular components of beaver milk successively rises to reach maximum value by the end of lactation. The results from the terminal period of lactation are in agreement with the data reported by Lavrov $(1938,1954)$ (Table 2). The largest fluctuations during lactation are observed in respect of fat and total protein contents, whereas the level of lactose, whey proteins and ash remains relatively constant.

It is clear that 7 analyses of beavers milk are not sufficient to characterize the course of lactation. The results constitute, however, a basis for further more detailed studies (actually in progress) on the lactation and milk composition of beavers. 


\section{REFERENCES}

Budsławski J., 1963: Chemia i analiza mleka oraz jego przetworów. Państw. Wyd. Roln. i Leś., Warszawa. L a v rov L. S., 1938: Opyt kletočnogo razviedienija rečnego bobra. Tr. Voronež. Gos. Zap. 1: 171-199. L a v r ov L. S., 1954: Biologičeskoje i zootechničeskoje obosnovanije rozviedienija bobrov na fermie. Tr. Voronež. Gos. Zap. 5: 7-25. S ła wi ń ski T., 1966: Badania nad składem chemicznym mleka nutrii w ciągu laktacji. Roczn. Nauk Roln. 87, B, 4: 763-771. Ż u ro w s k W., 1970: Zastosowanie trankwiliny przy kojarzeniu par i łączeniu w grupy bobrów europejskich (Castor fiber L.). Med. wet. 26, 2: 111-112.

Polish Academy of Science, Institute of Genetics and Animal Breeding, Popielno, pow. Pisz. Accepted, May 30, 1971.

Anna FEDYK \& Andrzej L. RUPRECHT

TAXONOMIC VALUE OF $\mathrm{M}_{1}$ MEASUREMENTS IN MICROTUS AGRESTIS

(L I N A E US, 1761) AND MICROTUS ARVALIS (P A L L A S, 1779)

TAKSONOMICZNA WARTOSC POMIAROW M, U MICROTUS AGRESTIS

(L I N A E S, 1761) I MICROTUS ARVALIS (P A L L A S, 1779)

An analysis was made of the variations in the measurements of $M_{1}$ teeth and position of foramen mandibulare in two species of voles, $M$ agrestis $(\mathrm{n}=272)$ and $M$. arvalis $(\mathrm{n}=118)$. The weight of $\mathrm{M}_{1}$ is of some assistance. $\mathrm{M}_{1}$ teeth weighing $>10.3 \mathrm{mg}$ correspond to $47.9 \%$ of the individuals of $M$. agrestis, while $\mathrm{M}_{1}<7.3 \mathrm{mg}-53.4 \%$ of $M$. arvalis. The relationship between the weight and height of crown of $\mathrm{M}_{1}$ on a correlation diagram, make it possible to distinguish $68.8 \%$ of $M$. agrestis and $64.1 \%$ of $M$. arvalis. This method may be of practical assistance in identifying fossil material cr material originating from owl pellets.

The two species of voles - M. agrestis and M. arvalis, differ in respect of skull dimensions and certain descriptive characters of the teeth and mandible (cf. Z immermann, 1955). Morphological characters are not, however, permanent and vary to a greater or lesser degree (cf. R örig \& Börner, 1905; Reichstein \& R e is e, 1965). In two other species of European voles, it is known that they show additional triangles on their $\mathrm{M}^{2}$ (K owalski, 1957; R u precht, 1967), however, this characteristic has never been found in the aboral end of this tooth, as it was sometimes observed in M. arvalis. On the other hand in M. agrestis a tendency has been observed to reduction of this part of $\mathrm{M}^{2}$. The position of foramen mandibulare also cannot always be considered reliable in identification of these two species on account of the occurrence of intermediate variations (cf. Krommenhoek \& Slob, 1967; Dien$\mathrm{sk}$ e, 1969). Difficulties of a taxonomic nature increase with the degree of damage to the bone material, which may occur in fossil material or that obtained from owl pellets. Therefore $\mathrm{Kromm}$ e n hoek \& S lob (1967) and Dienske (1969) considered both the size, and descriptive characters of the skull, mandible and teeth to differentiate between $M$. agrestis and $M$. arvalis. 